\title{
Production of sexuals in the stingless bee Trigona (Lepidotrigona) ventralis flavibasis Cockerell (Apidae, Meliponini) in northern Vietnam ${ }^{1}$
}

\author{
Tong X. CHINH ${ }^{\mathrm{a}, \mathrm{b} *}$, Marinus J. SOMMEIJER ${ }^{\mathrm{a}}$ \\ ${ }^{a}$ Department of Social Insects, Utrecht University, PO Box 80.086, NL- 3508 TB Utrecht, The Netherlands \\ b Present address: Bee Research and Development Centre, Ngo 68 Nguyenhong, Langha, Dongda, \\ Hanoi, Vietnam
}

Received 23 October 2003 - revised 1 June 2004 and 8 January 2005 - accepted 25 January 2005

Published online 13 September 2005

\begin{abstract}
In a two-year study on the stingless bee Trigona ventralis under field conditions in Vietnam, production of males and gynes was investigated in ten colonies. Male production in this species was found to be periodic. Typically, colonies produced a batch of males in a period of several weeks. At the population level, however, males were found throughout the year, since male production was not synchronized between colonies. Male production varied significantly among various months and between the rainy and the dry season. The number of males produced was positively correlated with numbers of brood cells, of food storage pots, and of emerging workers. Unlike the clumped male production in a certain colony, gynes were continuously produced in all colonies at low numbers, but seasonal effects on their numbers were found similar to effects on the numbers of males. In a previous study, the same periodical production of males in individual colonies without synchronization between colonies was found in a new world-species, Melipona favosa. This suggests that the mechanisms underlying allocation of resources between sexes may be general for a number of stingless bees.
\end{abstract}

Stingless bee / male production / gyne production / food reserves / colony population dynamics / Trigona

\section{INTRODUCTION}

The highly eusocial group of stingless bees (Apidae, Meliponini) is widely distributed in tropical and southern subtropical areas throughout the world. The numerous species of these bees show considerable diversity in morphology, body size and nest architecture. However, all species have the characteristic of mass-provisioning brood cells prior to oviposition, as found in solitary bees. The typical provisioning and oviposition behavior is described by Sakagami (1982). Of the presently described 374 species worldwide, belonging to 23 genera and 18 subgenera, about 43 species (two genera: Lisotrig- ona and Trigona comprising three subgenera: Heterotrigona, Homotrigona, and Lepidotrigona) occur in the Asian region (Michener, 2000). The subgenus Lepidotrigona prevails in this region with four species (Sakagami and Yamane, 1984). Very little has been published on the biology of stingless bees of the Asian region. No information is available on the production of sexuals and on reproductive behavior.

Species of Trigona produce gynes in typical "royal cells" that are distinctly larger than cells from which workers and males emerge. Queen determination is nutritionally regulated through the quantity and the quality of larval food provisioned (Michener, 1974). Colonies of Trigona

\footnotetext{
* Corresponding author: txchinh@hn.vnn.vn
}

${ }^{1}$ Manuscript editor: Marla Spivak 
bees rear just a few gynes continuously. This is fundamentally different from Melipona colonies that permanently produce larger numbers of gynes (Sakagami, 1982; Ratnieks, 2001; Sommeijer et al., 2003a,b; Sommeijer and de Bruijn, 2003). In contrast to honeybees (Ratnieks, 1993; Strassmann, 2001; Oldroyd et al., 2001), workers with active ovaries are common in queenright stingless bee colonies. In several species, workers feed the queen by laying trophic eggs (Beig, 1972; Bego, 1982, 1990; Sakagami, 1982). Besides laying trophic eggs, workers also oviposit male producing eggs (Kerr, 1950; Machado et al., 1984; ImperatrizFonseca and Kleinert, 1998; Sommeijer and van Buren, 1992; Sommeijer et al., 1999; Koedam et al., 2001; Tóth et al., 2002; Chinh et al., 2003; Paxton et al., 2003; Sommeijer et al., 2003a). Recent publications confirm that male production by workers is common in stingless bees (Tóth et al., 2004).

The influence of seasonal variations in food availability on male production in stingless bees has been a topic of study (Bego, 1990; van Benthem et al., 1995; van Veen et al., 1999; Grosso et al., 2000; Moo-Valle et al., 2001; Sommeijer et al., 2003a), but the precise relation is still unclear. Our study on male production in Melipona favosa established that males of this species are produced in distinct periods, asynchronously in different colonies. As a consequence, males are produced throughout the year at population level, but in clumped periods at the colony level (Chinh et al., 2003). Most studies on this topic are either not detailed enough to reveal distinct periods of male production at the colony level, or they do not include detailed observations throughout the year on a series of colonies to address the question whether or not male production is seasonal.

To understand male and gyne production mechanisms in stingless bees it is important to investigate the possible effects of environmental factors in areas where natural climatic conditions reveal more distinct seasonal variation than in areas where previous studies were carried out. The mountain-forest area of the northern part of Vietnam, where stingless bees are common and the climate varies considerably through the year, was considered to be suitable for such a study. In the present study, we investigated how resources are allocated between sexes and castes, and which colonial and cli- matic factors influence these processes under natural conditions in northern Vietnam.

\section{MATERIALS AND METHODS}

Observations were done on ten nests of Trigona (Lepidotrigona) ventralis flavibasis Cockerell. In April 1999, the colonies were transferred from their natural nest cavities in hollow trees to observation hives and installed at our field station. The research site was in the natural habitat of the bees. This study area was in the bufferzone of Cuc Phuong National Forest, which is a section of the primary tropical rain forest that remains on the limestone mountains near the Red River Delta. The Cuc Phuong forest comprises an area of 22220 ha and is situated $100 \mathrm{~km}$ Southwest of Hanoi, Vietnam $\left(20^{\circ} 14^{\prime}-20^{\circ} 24^{\prime} \mathrm{N}\right.$ and $105^{\circ} 29^{\prime}-$ $105^{\circ} 44^{\prime}$ E, $350 \mathrm{~m}$ above sea level). The field data were collected from June 1999 to December 2000.

To study the emergence of workers, gynes and males we used the technique developed at Utrecht University (Sommeijer et al., 2003a). The colonies were kept in observation hives $(\mathrm{W} \times \mathrm{L} \times \mathrm{H}: 22 \times 40 \times 17 \mathrm{~cm})$, which were covered by glass lids to follow behaviors. The bees could freely fly out from the observation hive through a plastic tube of $7 \mathrm{~mm}$ diameter that passed through the wall. A small annex box was connected to each observation hive that served as a semiseparated place for the emergence of bees. Mature brood cells were regularly taken out of the brood nest and placed in the annex box. Adult workers of the major nest were able to move freely between major nest and annex box. Newly emerged bees that normally remain more than a day on the combs from which they emerge, were collected daily from the emergence box so that we could count their numbers and identify workers, gynes and males. After classifying the emerged adults, they were reintroduced into the main brood-nest.

Every fortnight, the total number of storage pots and number of brood combs were measured as an estimate of colony development. The number of brood cells was calculated by estimating the average radius of the circular combs that was measured by drawing circular comb outlines on a transparent plastic sheet. Then the number of cells for each comb was calculated using the formula: $\mathrm{No}=20.5 \times \pi \mathrm{r}^{2}$ (No: cell total number; 20.5: average cell number per square $\mathrm{cm}$; $\mathrm{r}$ : average radius of a comb). The total number of cells per colony was corrected for the holes in mature combs with centrally emerging brood.

Weather data were obtained from the National Hydrometeorology Station in Cuc Phuong forest, located about $100 \mathrm{~m}$ from our field laboratory. The climate in this area is characterized by a dry and a rainy season. The rainy season lasts from May to 

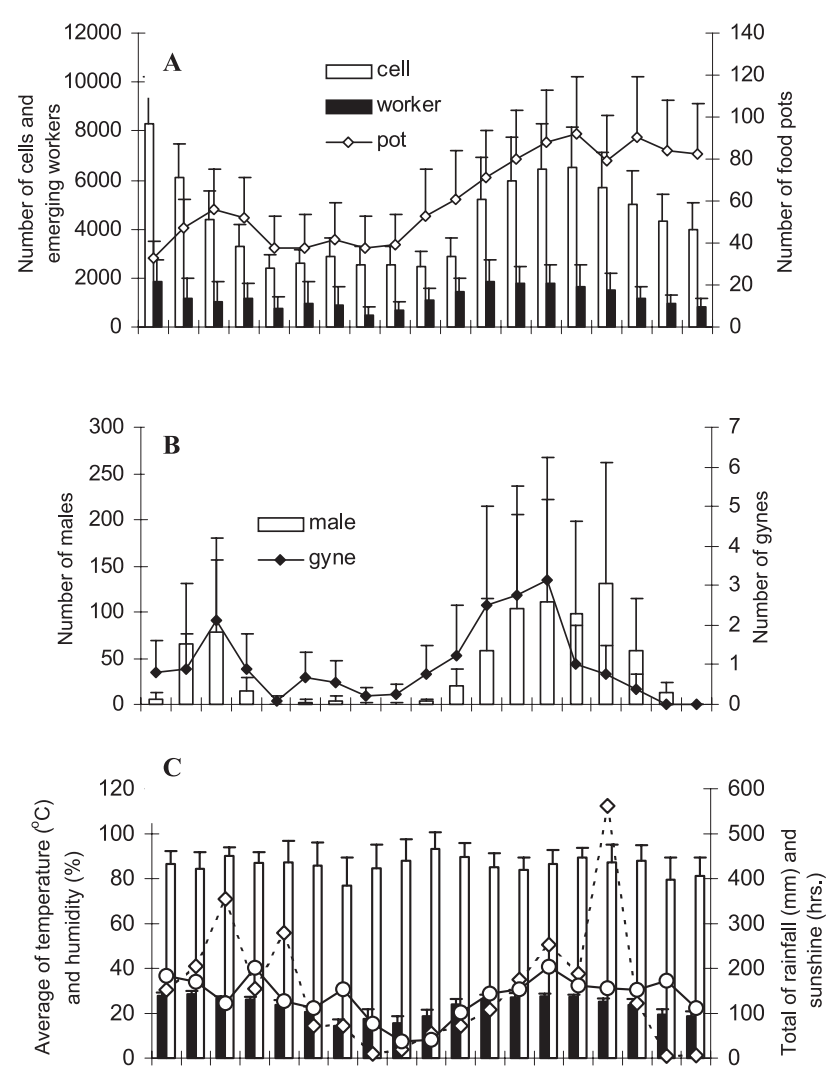

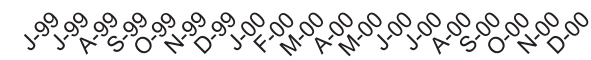

Month of the year

Figure 1. (A) Monthly average number of brood cells and storage pots (mean $+\mathrm{SE})$ and of emerging workers (mean $+\mathrm{SD}$ ); (B) emerging males and gynes; (C) average, temperature $\left({ }^{\circ} \mathrm{C}\right)$, relative humidity $(\%)$, rainfall $(\mathrm{mm})$ and sunshine $(\mathrm{h})$.

November with a daily average temperature of $25^{\circ} \mathrm{C}$ and a total precipitation of $1411 \mathrm{~mm}^{3}(90 \%$ of the total annual rainfall). The dry season runs from December to April with a daily average temperature of $17^{\circ} \mathrm{C}$ and a total precipitation of $163 \mathrm{~mm}^{3}$ (see Fig. 1C for detailed climatic conditions).

Mixed-effects Poisson regression analysis (Hedeker and Gibbons, 1996 and MIXPREG 1.0 program by Donald Hedeker) was performed to test for fluctuations in the production of males and gynes across years and seasons. "Year", "Season" (rainy season, May-November, or dry season) and the number of food pots were used as explanatory variables, and "Colony" was coded as a random factor. ANOVA was used to test for the significance of seasonal and intercolony variation in the number of brood cells produced. Hereby, the number of pots was used as covariate. The temporal clustering of emerging males in a colony was tested by calculating the index of dispersion, the ratio of the variance over the mean, on the observed number of emerging males produced per week. We also used the runs test for this analysis. Spearman rank correlation (two tailed) tests were used to investigate the relationship between the production of sexuals, colonial parameters and climatic factors.

\section{RESULTS}

\subsection{Colony development in T. ventralis}

In our colonies, most brood cells and stored food pots were found in the rainy season from May to September. In the dry season, both the brood cells and food stores diminished (Fig. 1A), but the food reserves were more constant compared to the number of brood cells. The amount of stored food varied significantly between the rainy and the dry season, and within colonies. The brood cell population varied significantly between the rainy and the dry seasons and among colonies (see Tab. I). The fluctuating brood cell 
Table I. Production of brood cells by "season" and "colony" with the number of pots as covariate, ANOVA.

Tests of Between-Subjects Effects

Dependent Variable: CELLS

\begin{tabular}{llccccc}
\hline Source & & Type III Sum of Squares & $d f$ & Mean Square & $F$ & Sig. \\
\hline Intercept & Hypothesis & $2.52 \mathrm{E}+08$ & 1 & $2.52 \mathrm{E}+08$ & 11.817 & 0.004 \\
& Error & $2.91 \mathrm{E}+08$ & 13.641 & $21340217^{1}$ & & \\
SEASON & Hypothesis & $1.37 \mathrm{E}+08$ & 1 & $1.37 \mathrm{E}+08$ & 24.937 & 0.000 \\
& Error & $8.39 \mathrm{E}+08$ & 153 & $5482598^{2}$ & & \\
COLONY & Hypothesis & $5.89 \mathrm{E}+08$ & 9 & 65489658 & 11.945 & 0.000 \\
& Error & $8.39 \mathrm{E}+08$ & 153 & $5482598^{2}$ & & \\
POT & Hypothesis & 55246031 & 1 & 55246031 & 10.077 & 0.002 \\
& Error & $8.39 \mathrm{E}+08$ & 153 & $5482598^{2}$ & & \\
\hline
\end{tabular}

${ }^{1} 0.264 \mathrm{MS}(\mathrm{COLONY})+0.736 \mathrm{MS}$ (Error).

${ }^{2} \mathrm{MS}$ (Error).

numbers were correlated with the numbers of stored food pots $(\mathrm{r}=0.48, P=0.036)$.

\subsection{Male production at the population level}

Of the total of 205536 emerging bees examined, 6456 were males $(3.1 \%)$. The monthly production of males is presented in Figure 1B. The production of males varied considerably among the colonies, but when the data of male production from the different colonies were combined it appeared that at population level males were produced throughout the year (Fig. 1B). Table IV shows that there was significant intercolony, seasonal and between-year variation in male production. In particular, male production was higher in the rainy season (MayNovember). Male production also increased significantly with the number of available food storage pots. The overall result of all the colonies combined indicated that a gradual increase from April to September was followed by a gradual decrease from November to March. The average percentage of emerging brood that was male ranged from $0.0 \%$ in December to $5.4 \%$ in September $(1.6 \pm 1.67 \%, \mathrm{n}=19$ months $)$, and was $3.1 \%$ overall. The percentage of colonies that produced males ranged from $0 \%$ in December (2000) to 100\% in August (1999) and May (2000), with an average of $42.6 \pm$ $27.83 \%(\mathrm{n}=19$ months $)$. All colonies produced males in August (1999), resulting in peak numbers of emerging males in that month; also, all observed colonies produced males in May (2000).

\subsection{Male production at colony level and related factors}

A statistical analysis of the index of dispersion as the ratio of the variance over the mean, on the observed number of males produced per week and the runs test (Tab. II) showed that at the colony level, male production occurred in distinct periods over the year, in most of the colonies (Fig. 2). These periods, referred to as Male Emergence Periods, MEPs (Chinh et al., 2003), alternated with short periods without male production. In general, the MEPs were not synchronized among colonies (Fig. 2). From the start of a typical MEP, male production gradually reached peak values after several weeks (sometimes to $100 \%$ of all daily emerging bees) and then the percentage of emerging males declined to zero again during several weeks (Fig. 2). During the observations from June 1999 to December 2000, a total number of 26 MEPs occurred in the ten colonies. The length of the MEPs was positively correlated with the number of males produced $(\mathrm{r}=0.49$, $P=0.01, \mathrm{n}=26)$. During this period, the number of MEPs per colony ranged from 1 to 4 , with an average of $2.6(\mathrm{SD}=1.1, \mathrm{n}=10)$. Detailed results of male production in the colonies are presented in Figure 1B. The production of males was positively correlated with the 
Table II. Mean, variance, index of dispersion (variance over the mean) and runs test of the number of males per colony over the weeks.

\begin{tabular}{lccccc}
\hline Colony & Number of weeks & Mean & Variance & Index of dispersion & Significance of runs test \\
\hline S1 & 83 & 0.131 & 0.117 & 0.893 & 0.000 \\
S2 & 83 & 1.851 & 7.789 & 4.208 & 0.000 \\
S3 & 83 & 0.154 & 0.173 & 1.123 & 0.000 \\
S4 & 83 & 0.407 & 0.685 & 1.683 & 0.000 \\
S5 & 83 & 0.528 & 0.450 & 0.852 & 0.000 \\
S6 & 83 & 0.206 & 0.188 & 0.913 & 0.000 \\
S7 & 83 & 0.976 & 6.434 & 6.592 & 0.000 \\
S8 & 35 & 0.024 & 0.020 & 0.833 & 0.000 \\
S9 & 25 & 0.138 & 0.150 & 1.087 & 0.000 \\
S10 & 83 & 0.104 & 0.092 & 0.885 & 0.018 \\
\hline
\end{tabular}

production of gynes in a colony $(\mathrm{r}=0.76, P<$ $0.0001, \mathrm{n}=19$ months).

\subsection{Queen cells and behavior of gynes}

Similar to other Trigona species, T. ventralis constructed special queen cells for the production of young queens. These queen cells were egg-shaped, and bigger and longer than the cells that give rise to males and workers. Queen cells were mainly constructed at the periphery of the brood combs. Only rarely did workers build queen cells in the center of the comb, in which case, the queen cells clearly protruded from the upper and the lower comb surface.

The newly constructed cells had a darkbrown and relatively thick wall. When reaching maturity they had a lighter color and the wall was much thinner since workers removed cerumen from developing cells. However, we did not observe that workers helped queens to emerge. Instead, we observed that a gyne herself gnawed away the upper top of the cell from which she subsequently emerged. In contrast, we observed that workers and males were usually helped by workers to emerge from their cells.

At the moment of emergence, virgin queens varied in their pigmentation, which ranged from pale-colored to dark brown-colored. The fuller pigmented, the more mobile a queen seemed to be, possibly because pigmentation depends on their age. After emergence, we observed some fully pigmented gynes hiding in between the combs and the involucrum.

In a few cases we observed clear worker aggression towards gynes. One young queen, just emerged from the cell, was bitten in her wing by a single worker. In a second case, two workers attacked a gyne. As a result of these attacks, some gynes had their wings damaged, others apparently escaped unharmed. Once we observed that a gyne was suddenly attacked by workers while she was walking around in the brood nest. During this observation the attacked gyne could finally escape. We could not observe whether newly emerged gynes were confined in special enclosures, e.g. constructed from involucrum material inside the nest (c.f. Imperatriz-Fonseca and Zucchi, 1995; Sakagami, 1982).

\subsection{Queen cells containing dead queens}

Of the total of 237 queen cells observed in the annex, $71(30 \%)$ contained dead queens. The phenomenon of queen cells containing dead adult gynes also occurred in natural nests. When opening a large natural nest from a tree in the forest, we encountered about 20 of these queen cells with live gynes next to five queen cells containing dead adult gynes. The natural broodnest of this species is difficult to open completely without seriously damaging the nest. Even in our observation boxes it was difficult to observe behavior inside the broodnest.

\subsection{Gyne production}

Of the total of 198914 emerging females examined, 166 were gynes $(0.08 \%)$. At the population level, gynes emerged from queen cells during most of the year (Fig. 1B). Unlike male production which occurred in distinct batches, 


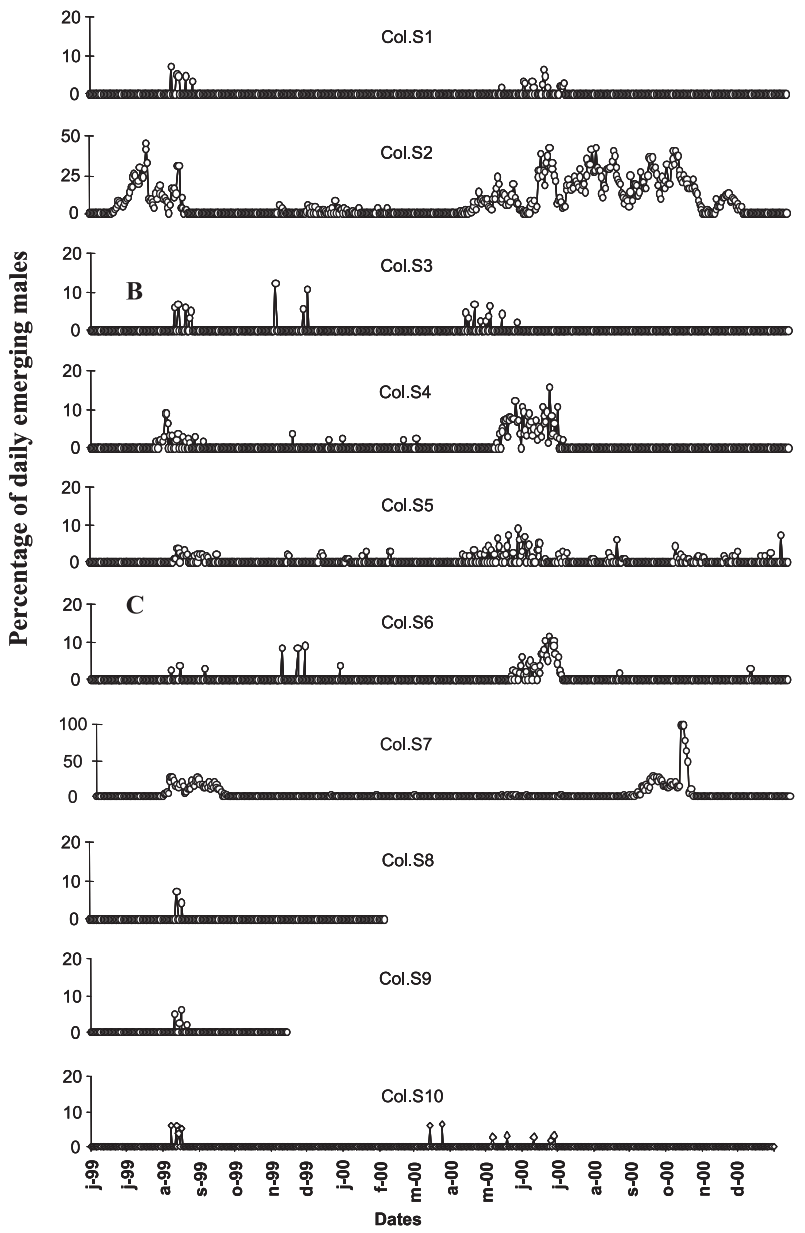

Figure 2. Periods with and periods without male emergence that occurred in the different colonies observed in the field.

gyne production at the colony level was more continuous. Hence, gynes were also produced in periods when no males were produced. Low numbers of gynes were found in January and February after which there was a gradual increase (Fig. 1). After the high values in June and July (on average 2.5 gynes/colony per month in July), gyne numbers decreased gradually. No gynes were found in the winter months of November and December. Similar to the production of males, the number of gynes fluctuated significantly between seasons, although to a lesser extent than for male production (Tab. IV). Unlike male production, the production of gynes (measured from June to December) was not significantly different between the two years. Correlations between the monthly production of gynes and climatic factors are presented in Table III.

\section{DISCUSSION}

\subsection{At the population level, males and gynes are synchronously produced over the season}

The production of sexuals in $T$. ventralis occurs over a long period of the year. Despite the considerable variation between the colonies we can conclude for both sexuals that their occurrence in the nests is common from March until September. In May we found already high values for gynes whereas male numbers were still low in that month. In September we observed the opposite tendency; male numbers were still high, but gyne numbers were already decreasing in that month. A seasonal production of sexuals is typical for Apis mellifera in temperate areas and some species of stingless 
Table III. Correlations (Spearman's rank, 2-tailed, $\mathrm{n}=19$ months) between the production of sexuals and colonial conditions and climatic factors.

\begin{tabular}{lccc}
\hline & Temp. & Rain. & Sun. \\
\hline \# of Cells & $0.80,0.000^{* *}$ & $0.47,0.041^{*}$ & $0.71,0.001^{* *}$ \\
\# of Workers & $0.75,0.000^{* *}$ & $0.45,>0.05$ & $0.56,0.013^{*}$ \\
\# of Pots & $0.19,>0.05$ & $0.06,>0.05$ & $0.29,>0.05$ \\
\# of Males & $0.76,0.001^{* *}$ & $0.66,0.002^{* *}$ & $0.55,0.014^{*}$ \\
\# of Gynes & $0.74,0.00^{* *}$ & $0.55,0.015^{*}$ & $0.32,>0.05$ \\
\hline
\end{tabular}

*, ** Correlation is significant at the 0.01 and 0.05 level, respectively.

Abbreviations: temp. $=$ temperature, rain. $=$ rainfall, sun. $=$ sunshine .

Table IV. Mixed-effects Poisson regression analysis of production of males and gynes.

\begin{tabular}{|c|c|c|c|c|}
\hline \multicolumn{5}{|c|}{ 1. Number of males } \\
\hline Variable & Estimate & $\begin{array}{l}\text { Stand. } \\
\text { Error }\end{array}$ & $\mathrm{Z}$ & $\begin{array}{c}P \text {-value } \\
\text { (2 tailed) }\end{array}$ \\
\hline Intercept & 1.24634 & 0.15933 & 7.82242 & 0.00000 \\
\hline Season & -0.87393 & 0.11345 & -7.70323 & 0.00000 \\
\hline Pot & 0.00966 & 0.00060 & 16.13525 & 0.00000 \\
\hline \multicolumn{5}{|c|}{ 2. Number of gynes } \\
\hline Variable & Estimate & $\begin{array}{l}\text { Stand. } \\
\text { Error }\end{array}$ & $\mathrm{Z}$ & $\begin{array}{c}P \text {-value } \\
\text { (2 tailed) }\end{array}$ \\
\hline Intercept & 0.21962 & 0.28436 & 0.77231 & 0.43993 \\
\hline Season & -0.75734 & 0.22103 & -3.42632 & 0.00061 \\
\hline Pot & 0.00755 & 0.00091 & 8.33111 & 0.00000 \\
\hline
\end{tabular}

bees have been reported to produce sexuals seasonally as well (Beig, 1972; Bego, 1990), M. subnitida (Sakagami, 1982), M. beecheii (van Veen et al., 1999; Moo-Valle et al., 2001) and T. angustula (Grosso et al., 2000). Our results show that the production of sexuals is highest in summer (correlations with temperature, rainfall and sunshine). The clear seasonality found is different from the production of sexuals in some tropical stingless bee species. In M. favosa, in Trinidad \& Tobago, male and gyne production occurred in all months of the year and variation in gyne production among the different months was not significant (Sommeijer et al., 2003a).

Our results showed that the number of gynes did not vary significantly in the period from June-December over the two years. However, the number of males fluctuated significantly. This indicates that the production of gynes is less influenced by seasonal factors. The low production of gynes in this species concurs with the low gyne production in another neotropical trigonine species, e.g. $0.006 \%$ in Tetragonisca angustula (van Veen and Sommeijer, 2000).

The difference in the number of males produced in the successive years can be explained by the fact that in the first year the colonies were just installed in the observation hives. The higher rainfall and subsequent higher honey flow in the second year may have contributed as an additional factor. The significant correlation between male production and stored food in the nest is in agreement with other findings (van Veen et al., 1999; Moo-Valle et al., 2001; Grosso et al., 2000). Colonies apparently invest more in production of sexuals when there are more food reserves. There may even be a direct link between pollen reserves and production of males. In T. ventralis it seems that only colonies with surplus food and with a large population of workers produce males for a long period in total over the year. In several species laying workers have been found to contribute to the production of drones (Toth et al., 2004). Egglaying workers are much involved in pollen uptake from the storage pots, probably because pollen consumption is necessary to produce eggs (Sommeijer et al., 1985). When ample food is available workers may therefore be stimulated to lay viable eggs leading to the production of males. However, the same correlation between pollen reserves and production of males has been found in Tetragonisca angustula, where the queen produces all males (Grosso et al., 2000), which implies that another mechanism must be involved in the production of males. In T. ventralis it is unclear if the workers 
contribute to the production of males; for the subspecies $T$. v. hoozana they have been reported to lay trophic eggs that are eaten by the queen (Sakagami and Yamane, 1987).

\subsection{Male production is in general clumped}

The periodic pattern of males emerging in clumps has been found earlier for $M$. favosa (Chinh et al., 2003), and also for $T$. postica (Bego, 1982, 1990), P. remota (Benthem et al., 1995) and M. subnitida (Koedam et al., 1999). For $M$. favosa we demonstrated that the clumped emergence of males results from the occurrence of reproductive (haploid) eggs laid by workers. These laying workers are active in repeating periods alternating with periods without male production (Chinh et al., 2003; Sommeijer et al., 2003a). The precise mechanism for the regulation of this rhythmic occurrence of reproductive laying workers in M. favosa is still unknown. Probably, the rhythmic occurrence of male production in $T$. ventralis is also the result of reproduction by laying workers. It is known that in various non-Melipona stingless bees, laying workers do contribute to the production of males (Beig, 1972; Bego, 1982, 1990; Koedam et al., 1999; Tóth et al., 2004). In our previous study on male production in $M$. favosa, we have suggested several possible explanations for the regulation of the periodic male production phenomenon based on reproduction by laying workers (Chinh et al., 2003). A function of this phenomenon may be that it may serve to prevent inbreeding. While certain colonies are producing males, others under the same conditions are not producing, even when they are situated very close to each other. At the population level, the asynchronous clumped male production phenomenon allows for the presence of males all over the season. Obviously, it is very costly for a colony to produce large numbers of males for a certain period. A colony may invest heavily in male production for some time, but it must allocate part of its resources to worker production in order to maintain a strong colony.

\subsection{Gyne production and behavior}

The common occurrence of dead gynes in the queen cells is a phenomenon not earlier reported for stingless bees. It may have resulted from workers preventing their emergence at moments when no new queens are needed. If gynes do emerge, we have evidence that workers generally approach them in an agonistic manner. During the development of a gyne in her cell, workers treat the cell in the same way as the other brood cells: the cell wall material is continuously removed which results in a gradually thinning cell wall. However, the workers apparently do not assist the gyne with emergence from her cell whereas they do assist other nestmates by opening the cells. Queen cells with completely developed gynes may therefore remain closed for some more days even when the gyne would be able to emerge. Some reports for other trigonine species indicate that gynes may be kept alive by workers in special enclosures to keep them available for moments when they might be needed (Engels and Imperatriz-Fonseca, 1990; ImperatrizFonseca and Zucchi, 1995). Gynes in such "prisons" are fed by the workers. This is clearly not the case in $T$. ventralis. The continuous presence of queen cells already guarantees that replacement gynes are present, which is necessary for colony survival if the old queen is lost. From the varying conditions from which queens emerge from their cells we conclude that queens often remain longer in their cells than would be necessary for their full development. Hence, their cells serve as "prisons", but the gynes are not fed and therefore cannot survive for a long time.

It is obvious that the production of sexuals varies considerably in the colonies in this study. Both, internal processes in the colony and seasonal factors seem to play a role in this. Two main conclusions can be drawn: 1 . in $T$. ventralis the production of sexuals occurs over most of the year, in varying numbers depending on the season; 2. population size and food reserves appear to be important factors for the production of males and gynes, whereas production of males is typically clumped per colony.

\section{ACKNOWLEDGEMENTS}

We thank Mr. Dinh Quyet Tam, director of National Bee Research and Development Centre, for his help and co-operation. Our thank is given to the staff of Cuc Phuong National Park and Cuc Phuong Commune for help. We are grateful for the 
enthusiastic help given by the family of Mr. Do Cao Tri in the Cuc Phuong Commune. We would like to express our gratitude to Prof. Charles D. Michener for the classification of the stingless bees. We thank Drs. E. Martens, Centre for Biostatistics at Utrecht University, for his valuable statistical analyses. Dr. Tom Wenseleers and an anonymous reviewer are thanked for suggestions for the improvement of this article. This study received financial support from The Royal Netherlands Embassy in Hanoi, Vietnam (grant No. VN016601-5) and the first author received scholarships from Utrecht University, The Netherlands, and from the United Nations University.

Résumé - Production de sexués chez l'abeille sans aiguillon Trigona (Lepidotrigona) ventralis flavibasis au Vietnam septentrional. Contrairement aux abeilles mellifères (Apidae, Apini), les ouvrières des abeilles sans aiguillon (Apidae, Meliponini) qui possèdent des ovaires actifs sont courantes dans les colonies d'abeilles avec reine. Chez plusieurs espèces, les ouvrières nourrissent la reine en pondant des œufs trophiques. À côté de cela, les ouvrières pondent aussi des œufs qui donnent des mâles. Notre étude antérieure sur la production de mâles chez Melipona favosa a montré que les mâles de cette espèce sont produits principalement par les ouvrières au cours de périodes distinctes et différentes selon les colonies. En conséquence les mâles sont produits tout au long de l'année au niveau de la population, mais par périodes groupées au niveau de la colonie (Chinh et al., 2003). Dans cet article nous avons étudié comment sont allouées les ressources entre les sexes et les castes et quels facteurs de la colonie et du climat influencent ces processus dans les conditions naturelles du Vietnam du nord. Les observations ont été faites sur 10 colonies de Trigona (Lepidotrigona) ventralis flavibasis Cockerell. Les colonies, qui nidifient dans des cavités naturelles dans des arbres creux, ont été transférées dans des ruches d'observation. L'émergence des ouvrières, des femelles et des mâles a été étudiée selon la technique mise au point à l'Université d'Utrecht (Sommeijer et al., 2003a).

La production de mâles chez T. v. flavibasis est périodique. Les colonies ont produit un lot de mâles sur une période de plusieurs semaines mais, au niveau de la population, les mâles étaient présents tout au long de l'année (Fig. 1B) car la production entre colonies n'était pas synchronisée (Fig. 2). La production de mâles a varié significativement d'un mois à l' autre et entre la saison sèche et la saison des pluies (Tab. I). Le nombre de mâles produit était corrélé positivement avec le nombre de cellules de couvain, le nombre de pots de réserve de nourriture et le nombre d'ouvrières naissantes. Contrairement à la production groupée de mâles dans une certaine colonie, les femelles ont été produites dans toutes les colonies de façon continue et en faible nombre, mais les saisons ont eu d'un point de vue quantitatif le même effet que sur les mâles (Tab. III). Puisque cette production périodique de mâles sans synchronisation entre colonies a déjà été trouvée chez Melipona favosa, cela suggère que les mécanismes sousjacents à l'affectation des ressources entre les sexes sont peut-être généraux pour un certain nombre d'espèces d'abeilles sans aiguillon. Nous avons trouvé aussi couramment des femelles mortes dans les cellules de reine. Il s'agit d'un phénomène qui n'a jamais été mentionné chez les abeilles sans aiguillon. Cela peut être dû au fait que les ouvrières empêchent leur émergence à un moment où la colonie n'a pas besoin de nouvelles reines.

On peut tirer deux conclusions principales : (i) la production de sexués chez $T$. ventralis a lieu tout au long de l'année en nombre variable selon la saison, (ii) la taille de la population et les réserves de nourriture semblent être des facteurs importants pour la production de mâles et de reines, et la production groupée de mâles par colonie est typique.

Trigona / abeille sans aiguillon / production de sexués / réserves de nourriture / dynamique de population / colonie

Zusammenfassung - Erzeugung von Geschlechtstieren bei der Stachellosen Honigbiene Trigona (Lepidotrigona) ventralis flavibasis (Apidae, Meliponini) im nördlichen Vietnam. Anders als bei Honigbienen (Apidae, Apini), kommen bei Stachellosen Bienen (Apidae, Meliponini) Arbeiterinnen mit aktiven Ovarien in weiselrichtigen Völkern häufig vor. Bei mehreren Arten füttern die Arbeiterinnen die Königinnen durch die Ablage von "trophischen" Eiern. Neben der Produktion dieser trophischen Eier legen die Arbeiterinnen auch Eier, aus denen Männchen entstehen. Unsere frühere Studie über die Produktion von Männchen bei Melipona favosa hatte gezeigt, dass die Männchen überwiegend von den Arbeiterinnen erzeugt werden. Dies geschieht zu ganz bestimmten Zeiten, die sich zwischen verschiedenen Kolonien unterscheiden. Als Folge werden in der Population zu jeder Jahreszeit Männchen erzeugt, bezüglich einzelner Kolonien aber nur zu bestimmten Zeiten (Chinh et al., 2003). In der vorliegenden Studie untersuchen wir, wie die Ressourcen zwischen Geschlechtern und Kasten aufgeteilt werden, und welche Kolonie- und Klimafaktoren diese Prozesse unter natürlichen Bedingungen in Nordvietnam beeinflussen. Die Untersuchungen wurden an 10 Nestern von Trigona (Lepidotrigona) ventralis flavibasis Cockerell durchgeführt. Die Kolonien wurden aus ihren natürlichen Nesthöhlen in hohlen Bäumen in Beobachtungsstöcke überführt. Zur Untersuchung des Schlupfes von Arbeiterinnen sowie von weiblichen und männlichen Geschlechtstieren verwendeten wir die an der Universität von Utrecht entwickelte Methode (Sommeijer et al., 2003a).

Die Produktion von Männchen bei Trigona (Lepidotrigona) ventralis flavibasis Cockerell erfolgte 
periodisch. Typischerweise produzierten die Kolonien periodisch im Abstand von mehreren Wochen jeweils einmal eine Anzahl von Männchen. Da die Kolonien nicht synchronisiert waren, wurden auf dem Populationslevel dagegen zu allen Jahreszeiten Männchen gefunden (Abb. 1B und 2). Die Männchenproduktion unterschied sich zwischen Monaten sowie zwischen der Regenzeit und der Trockenzeit signifikant (Tab. I). Die Anzahl erzeugter Männchen war positiv mit der Anzahl von Brutzellen, von Futtervorratsbehältern und von schlüpfenden Arbeiterinnen korreliert. Anders als die pro Kolonie nur während eines kurzen Zeitabschnitts erfolgende Produktion von Männchen wurden in allen Kolonien zu allen Zeiten weibliche Geschlechtstiere in geringen Anzahlen erzeugt. Ihre Anzahl zeigte ähnliche saisonale Abhängigkeit wie die der Männchen (Tab. III). Bereits früher war eine ähnliche periodische Produktion von Männchen in Einzelkolonien ohne Synchronisierung zwischen den Kolonien bei der neotropischen Melipona favosa beschrieben worden. Dies weist darauf hin, dass bei verschiedenen Stachellosen Bienen die Aufteilung der Ressourcen zwischen den Geschlechtern nach einem ähnlichen Mechanismus erfolgt.

Üblicherweise fanden wir auch tote weibliche Geschlechtstiere in den Königinnenzellen. Über dieses Phänomen wurde bei Stachellosen Bienen zuvor nicht berichtet. Möglicherweise könnten die Arbeiterinnen den Schlupf verhindert haben wenn keine neuen Königinnen benötigt wurden. In Bezug auf die Erzeugung von Geschlechtstieren bei T. ventralis können zwei Hauptschlussfolgerungen gezogen werden: 1. Die Erzeugung von Geschlechtstieren erfolgt über das ganze Jahr, die Anzahlen schwanken in Abhängigkeit von der Saison; 2. Die Stärke der Population und des Futtervorrates scheinen wichtige Faktoren für die Produktion von Männchen und weiblichen Geschlechtstieren zu sein, wobei die Männchen typischerweise in den Kolonien während einer kurzen Periode erzeugt werden.

Stachellose Bienen / Trigona / Männchenproduktion / Produktion weiblicher Geschlechtstiere / Nahrungsvorräte / Koloniepopulationsdynamik

\section{REFERENCES}

Bego L.R. (1982) On social regulation in Nannotrigona (Scaptotrigona) postica Latreille, with special reference to male production cycles (Hym, Apidae, Meliponinae), Bolm. Zool. Univ. S. Paulo 7 , 181-196.

Bego L.R. (1990) On social regulation in Nannotrigona postica Latreille, with special reference to productivity of colonies (Hymenoptera, Apidae, Meliponinae), Rev. Bras. Entomol. 34, 721-738.

Beig D. (1972) The production of males in queenright colonies of Trigona (Scaptotrigona postica), J. Agric. Res. 11, 33-39.
Benthem F.D.J. van, Imperatriz-Fonseca V.L., Velthuis H.H.W. (1995) Biology of the stingless bee Plebeia remota (Holmberg): Observations and evolutionary implications, Insectes Soc. 42, 71-78.

Chinh T.X., Grob G.B.J., Meeuwsen F.J.A.J., Sommeijer M.J. (2003) Patterns of male production in the stingless bee Melipona favosa (Apidae, Meliponini), Apidologie 42, 161-170.

Engels W., Imperatriz-Fonseca V.L. (1990) Caste development, reproductive strategies, and control of fertility in honey bees and stingless bees, in: Engels W. (Ed.), Social Insects: An evolutionary approach to castes and reproduction, SpringerVerlag, Berlin, Heidelberg, pp. 167-230.

Grosso A.F., Bego L.R., Martinez A.S. (2000) The production of males in queenright colonies of Tetragonisca angustula angustula (Hymenoptera, Meliponinae), Sociobiology 35, 475-485.

Hedeker D., Gibbons R.D. (1996) MIXREG: a computer program for mixed-effects regression analysis with autocorrelated errors, Comput. Meth. Prog. Bio. 49, 229-252.

Imperatriz-Fonseca V.L., Zucchi R. (1995) Virgin queens in stingless bee (Apidae, Meliponinae) colonies: a review, Apidologie 26, 231-244.

Imperatriz-Fonseca V.L., Kleinert A.D.P. (1998) Worker reproduction in the stingless bee species Friesella schrottkyi (Hymenoptera: Apidae: Meliponinae), Entomol. Gen. 23, 169-175.

Kerr W.E. (1950) Genetic determination of castes in the genus Melipona, Genetics 35, 143-152.

Koedam D., Contrera F.A.L., Imperatriz-Fonseca V.L. (1999) Clustered male production by workers in the stingless bee Melipona subnitida Ducke (Apidae, Meliponinae), Insectes Soc. 46, 387-391.

Koedam D., Velthuis H.H.W., Dohmen M.R., ImperatrizFonseca V.L. (2001) The behaviour of laying workers and the morphology and viability of their eggs in Melipona bicolor bicolor, Physiol. Entomol. 26, 254-259.

Machado M.F.P.S., Contel E.P.B., Kerr W.E. (1984) Proportion of males sons-of-the-queen and sonsof-workers in Plebeia droryana (Hymenoptera, Apidae) estimated from data of an MDH isozymic polymorphic system, Genetica Dordrecht 65, 193-198.

Michener C.D. (1974) The social behavior of the bees, Harvard University Press, Cambridge.

Michener C.D. (2000) The bees of the World, The John Hopkins University Press, Baltimore, MD.

Moo-Valle H., Quezada-Euán J.J.G., Wenseleers T. (2001) The effect of food reserves on the production of sexual offspring in the stingless bee Melipona beecheii (Apidae, Meliponini), Insectes Soc. 48, 398-403.

Oldroyd B.P., Wossler T.C., Ratnieks F.L. (2001) Regulation of activation in worker honey-bee 
(Apis mellifera): larval signal production and adult response thresholds differ between anarchistic and wild-type bees, Behav. Ecol. Sociobiol. 50, 366370.

Paxton R.J., Bego L.R., Shah M.M., Mateus S. (2003) Low mating frequency of queens in the stingless bee Scaptotrigona postica and worker maternity of males, Behav. Ecol. Sociobiol. 53, 174-181.

Ratnieks F.L.W. (1993) Egg laying, egg-removal, and ovary development by workers in queenright honey bee colonies, Behav. Ecol. Sociobiol. 32, 191-198.

Ratnieks F.L.W. (2001) Heirs and spares: caste and conflict and excess queen production in Melipona bees, Behav. Ecol. Sociobiol. 50, 467-473.

Sakagami S.F. (1982) Stingless bees, in: Hermann H.R. (Ed.), Social Insects III, Academic Press, New York, pp. 361-432.

Sakagami S.F., Yamane S. (1984) Notes on taxonomy and nest architecture of the Taiwanese stingless bee Trigona (Lepidotrigona) ventralis hoozana, Bull. Fac. Educ., Ibaraki Univ., Nat. Sci. 33, 3748.

Sakagami S.F., Yamane S. (1987) Oviposition behavior and related notes of the Taiwanese stingless bees Trigona (Lepidotrigona) ventralis hoozana, J. Ethol. 5, 17-27.

Sommeijer M.J., de Buijn L.L.M., van de Guchte C. (1985) The social food flow within the colony of a stingless bee Melipona favosa, Behaviour 92, $39-58$.

Sommeijer M.J., van Buren N.W.M. (1992) Male production by laying workers in queenright colonies of Melipona favosa (Apidae, Meliponinae), in: Billen J. (Ed.), Biology and Evolution of Social Insects, Leuven University Press, Leuven, Belgium, pp. 89-97.

Sommeijer M.J., Chinh T.X., Meeuwsen F. (1999) Behavioural data on the production of males by workers in the stingless bee Melipona favosa (Apidae, Meliponinae), Insectes Soc. 46, 92-93.

Sommeijer M.J., Bruijn L.L.M. de (2003) Why do workers of Melipona favosa chase their sistergynes out of the nest? Proceedings of the Section Experimental and Applied Entomology, N.E.V., Amsterdam 14, pp. 45-48.

Sommeijer M.J., de Bruijn L.L.M., Meeuwsen F.J.A.J., Slaa E.J. (2003a) Reproductive behaviour of stingless bees: nest departure non-accepted gynes and nuptial flights in Melipona favosa (Hymenoptera: Apidae, Meliponini), Entomol. Ber. 63, 7-13.

Sommeijer M.J., Bruijn L.L.M. de, Meeussen F.J.A.F., Martens E.P. (2003b) Natural patterns of caste and sex allocation in the stingless bees Melipona favosa and $M$. trinitatis related to workers behaviour, Insectes Soc. 50, 38-44.

Strassmann J. (2001) The rarity of multiple mating by female in social Hymenoptera, Insectes Soc. 48, $1-13$.

Tóth E., Strassmann J.E., Nogueira-Neto P. ImperatrizFonseca V.L., Queller D.C. (2002) Male production in stingless bees: variable outcomes of queenworker conflict, Mol. Ecol. 11, 2661-2667.

Tóth E., Queller D.C., Dollin A., Strassmann J.E. (2004) Conflict over male parentage in stingless bees, Insectes Soc. 51, 1-11.

Van Veen J.W., Sommeijer M.J. (2000) Colony reproduction in Tetragonisca angustula (Apidae, Meliponini), Insectes Soc. 47, 70-75.

Van Veen J.M., Sommeijer M.J., Arce H.G. (1999) The role of colony development and resource availability in the regulation of queen production in Melipona beecheii (Apidae, Meliponini), in: van Veen J.W., Colony reproduction in stingless bees, Ph.D. thesis, Utrecht Univ., Litografia Imprenta Lil, S.A. San Jose, pp. 80-87. 